\title{
Inhibitory effect of cerebrospinal fluid on the growth of meningococci and pneumococci
}

\author{
M HASSAN-KING, HC WHITTLE, BM GREENWOOD \\ From the Department of Medicine, Ahmadu Bello University Hospital, Zaria, Nigeria
}

SUMMARY Initial cerebrospinal fluid (CSF) samples obtained from patients with pneumococcal meningitis usually contain far greater numbers of bacteria than initial CSF samples obtained from patients with meningococcal meningitis. Normal CSF was found to have an inhibitory effect on the growth of group A meningococci but not on type 1 pneumococci. The inhibitory effect of normal CSF was abolished by dialysis, indicating that the inhibitory factor has a low molecular weight. Heating normal CSF to $62.5^{\circ} \mathrm{C}$ for 30 min resulted in a considerable reduction in the inhibitory effect, indicating that the inhibitory factor is heat labile.

Initial cerebrospinal fluid (CSF) samples obtained from patients with pneumococcal meningitis usually contain far greater numbers of bacteria than initial CSF samples obtained from patients with meningococcal meningitis The high bacterial counts found in patients with pneumococcal meningitis may relate to the poor prognosis of patients with this condition. In purulent meningitis bacteria multiply mainly in the meninges, but the CSF acts as the circulating medium through which bacteria are carried to infect other parts of the subarachnoid space. It is possible that the high number of bacteria found in pneumococcal CSFs may be due to the fact that normal CSF serves as an enhancing medium for the growth of pneumococci while it has the opposite effect on the growth of meningococci. The object of this investigation was to test the validity of this supposition.

\section{Material and methods}

\section{CSF SAMPLES}

Normal CSF samples were obtained from patients suspected on clinical grounds of having meningitis but whose CSF subsequently proved to be normal, as shown by the absence of bacteria and white blood cells. Samples were collected before the start of any treatment.

CSF samples were obtained from patients with

Present address: MRC Laboratories, Fajara, Nr Banjul, The Gambia.

Accepted for publication 3 January 1984 meningococcal or pneumococcal meningitis on the day of admission to hospital, before the start of antibiotic treatment. Diagnosis was confirmed by countercurrent immunoelectrophoresis' ${ }^{1}$ or latex agglutination. $^{2}$

\section{ROUTINE LABORATORY INVESTIGATIONS}

White cell and bacterial counts were performed on CSF samples as soon as possible after collection. White cells were counted in an improved Neubauer counting chamber. CSF was diluted $1 / 10$ in counting fluid. Bacteria were counted in a Thoma counting chamber using a phase contrast microscope. Turbid samples were diluted appropriately in phosphate buffered saline (PBS) so that there were between two and 10 bacteria per square. Pairs of bacteria were counted as one; bacteria present within a leucocyte were not counted. After white cell and bacterial counts had been made samples were centrifuged for $10 \mathrm{~min}$ at $3000 \mathrm{rpm}$ and the supernatant removed and stored at $-20^{\circ} \mathrm{C}$. Deposits were cultured on blood agar plates for pneumococci and on Mueller Hinton agar plates containing polymyxin and vancomycin for meningococci. Organisms were identified by standard bacteriological methods, using the optochin test for pneumococci and group specific antisera for typing meningococci.

\section{MEASUREMENT OF BACTERIAL GROWTH IN} NORMAL AND DISEASED CSF SAMPLES

${ }^{3} \mathrm{H}$-thymidine assay

Ten strains of group A meningococci and 10 strains of type 1 pneumococci isolated from patients with 
meningitis were used. A loopful of an $18 \mathrm{~h}$ culture of each organism was inoculated into $10 \mathrm{ml}$ tripticase soy broth (TSB) and incubated for up to $3 \mathrm{~h}$ at $37^{\circ} \mathrm{C}$ in a shaking water bath to achieve log phase culture. The bacteria were then washed twice in medium 199 and suspended in the same medium at a concentration corresponding to an optical density of 0.3 , measured at $650 \mathrm{~nm}$ in a Pye Unicam SP 600 ultraviolet spectrophotometer. Each strain of bacterium was grown in two diseased CSF samples, including the one from which it was isolated, normal $\mathrm{CSF}$, and medium 199 adjusted to a $\mathrm{pH}$ of 7.3. Reaction mixtures were set up in duplicate in ster Falcon plastic tubes, comprising $0.1 \mathrm{ml}$ bacterial suspension and $0.4 \mathrm{ml} \mathrm{CSF}$ or medium 199. One microcurie of $6^{3} \mathrm{H}$-thymidine solution, specific activity $5 \mathrm{Ci} / \mathrm{mmol}$ (185 G Bq) (Radiochemical Centre, Amersham), was added to each tube with a Hamilton precision syringe. The tubes were incubated at $37^{\circ} \mathrm{C}$ in a shaking water bath for $2 \mathrm{~h}$, after which time the labelling procedure was terminated by washing the bacteria twice in cold PBS at $4^{\circ} \mathrm{C}$. The bacteria were solubilised with $10 \%$ trichloroacetic acid and $1 \mathrm{~N}$ sodium hydroxide. Digests $(0 \cdot 1 \mathrm{ml})$ were transferred to glass scintillation vials containing $10 \mathrm{ml}$ of scintillation fluid. The scintillation fluid was made up of toluene based NE 233 containing $20 \%$ solubiliser NE 520 to incorporate water in the sample. Any possibility of chemiluminescence or quenching was eliminated by neutralising the samples with $10 \mu$ of $1 \mathrm{~N}$ glacial acetic acid. The samples were left for $30 \mathrm{~min}$ at room temperature before counting for $1 \mathrm{~min}$ in a Nuclear Enterprise LSC 1 liquid scintillation counter.

\section{Colony counting method}

A loopful of an $18 \mathrm{~h}$ culture of each isolate was incubated in TSB as previously described. The concentration of each organism was adjusted in sterile PBS to contain $10^{9}$ organisms/litre. Bacterial suspension $(0.1 \mathrm{ml})$ was added to $0.4 \mathrm{ml}$ of normal CSF or medium 199 in sterile Falcon plastic tubes. Samples $(50 \mu \mathrm{l})$ were then removed from each tube and plated on to previously dried Mueller-Hinton agar plates for meningococci or on to similarly treated blood agar plates for pneumococci. The tubes were incubated at $37^{\circ} \mathrm{C}$ in a shaking water bath. At hourly intervals $50 \mu \mathrm{l}$ samples were removed from each tube and plated out as above. The experiment was allowed to run for $5 \mathrm{~h}$, after which time the plates were incubated overnight at $37^{\circ} \mathrm{C}$ in $5 \%$ carbon dioxide and bacterial colonies counted with a Gallenkamp colony counter.

\section{CHARACTERISATION OF THE INHIBITORY FACTOR}

Removal of immunoglobulins from normal CSF

Aliquots of normal CSF were mixed with equal volumes of a 1/10 dilution of anti-whole-humanimmunoglobulin antiserum (Hyland Laboratories). The mixture was incubated at $37^{\circ} \mathrm{C}$ for $1 \mathrm{~h}$ and then for $24 \mathrm{~h}$ at $4^{\circ} \mathrm{C}$. It was then centrifuged for $20 \mathrm{~min}$ at

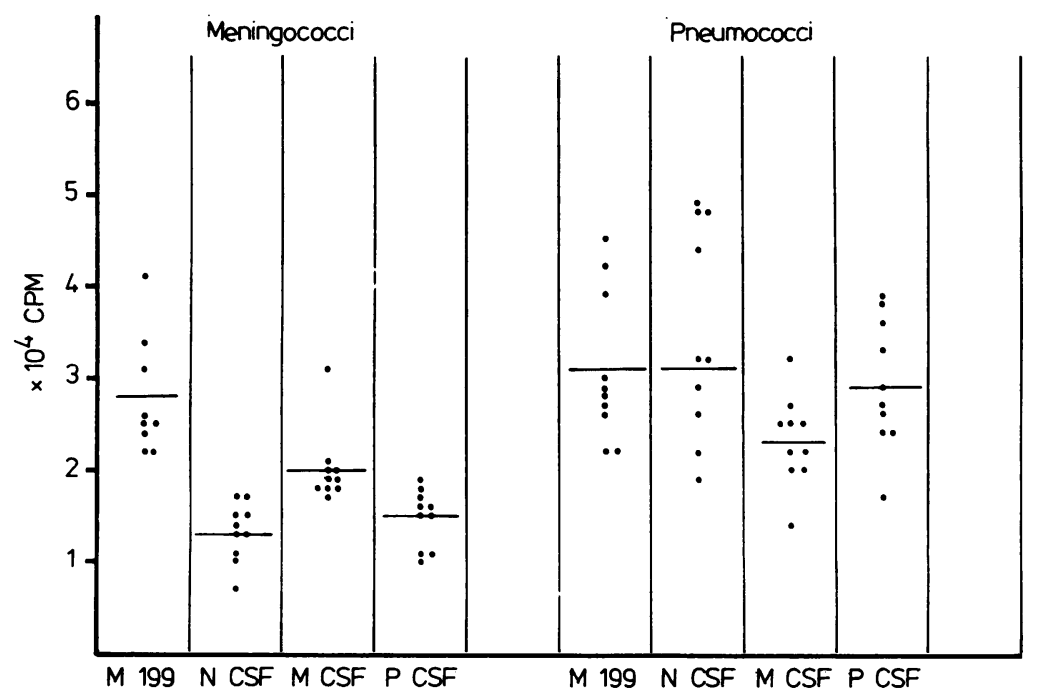

Fig. 1 Growth of meningococci and pneumococci, as measured by thymidine uptake in medium 199 (M 199), in normal cerebrospinal fuid (NCSF) and in CSF from patients with meningococcal (MCSF) or pneumococcal (PCSF) meningitis. Horizontal bars indicate mean counts/min (CPM). 
$12000 \mathrm{rpm}$, after which the supernatant was removed and used for growing meningococci. All the procedures were carried out under sterile conditions.

\section{Effect of heating normal CSF}

Pooled normal CSF was tested for inhibitory activity on meningococci after heating at $56^{\circ} \mathrm{C}$ and $62.5^{\circ} \mathrm{C}$ for $30 \mathrm{~min}$.

\section{Effect of dialysing normal CSF}

Pooled normal CSF was dialysed overnight against PBS and then tested for inhibitory activity on meningococci. Dialysis was carried out in Visking tubing with a pore size of about 10000 daltons.

\section{Results}

CSF BACTERIAL COUNTS IN MENINGOCOCCAL AND PNEUMOCOCCAL MENINGITIS

The bacterial counts found in initial CSF samples from 27 sequentially studied patients with pneumococcal meningitis (mean 235.8 $\times 10^{9} / 1$; range $\left.2 \cdot 2-1000 \times 10^{\%} / 1\right)$ were considerably higher than those found in CSF samples obtained from 24 consecutive patients with group A meningococcal meningitis (mean 30.6 $\times 10^{9} / 1$; range $1.2-124 \times$ $\left.10^{9} / 1\right)(\mathrm{p}<0 \cdot 001)$. In contrast, the mean white cell count in the CSF of 27 sequentially studied patients with pneumococcal meningitis (mean $7.0 \times 10^{9} / 1$; range $\left.0-77 \times 10^{9} / 1\right)$ was similar to the mean white cell count recorded in 24 consecutive patients with group A meningococcal meningitis (mean $11.4 \times$

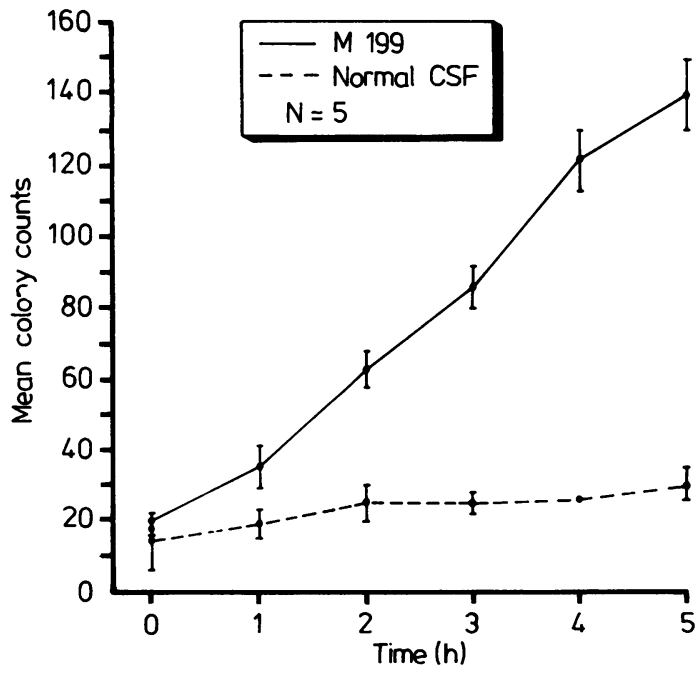

Fig. 2 Growth of meningococci in medium 199 (M 199) and in normal cerebrospinal fuid (CSF). Points represent mean $\pm l$ standard error of the mean; $n=$ number of experiments.
$10^{9} / 1$; range $\left.0 \cdot 3-50 \times 10^{9} / 1\right)$.

GROWTH OF MENINGOCOCCI AND PNEUMOCOCCI IN NORMAL AND DISEASED CSF

The growth of meningococci and pneumococci, as assessed by thymidine uptake, in medium 199, in normal CSF, and in CSF obtained from patients with meningococcal or pneumococcal meningitis is shown in Fig. 1. The growth of meningococci in normal CSF was significantly less than that in medium 199 $(p<0.001)$. In contrast, pneumococci grew equally well in normal CSF and in medium 199. Growth of meningococci was significantly inhibited by CSF from patients with pneumococcal meningitis ( $p$ $<0.001$ ), and the growth of pneumococci was significartly inhibited by CSF from patients with meningococcal meningitis $(p<0 \cdot 01)$. Pneumococci showed a higher growth rate in homologous CSF than did meningococci.

The growth rates of meningococci and pneumococci in medium 199 and in normal CSF as assessed by colony counting are shown in Figs. 2 and 3. Growth of meningococci, but not pneumococci, was inhibited significantly by normal CSF.

\section{NATURE OF THE INHIBITORY FACTOR IN}

NORMAL CSF

The nature of the inhibitory factor present in normal

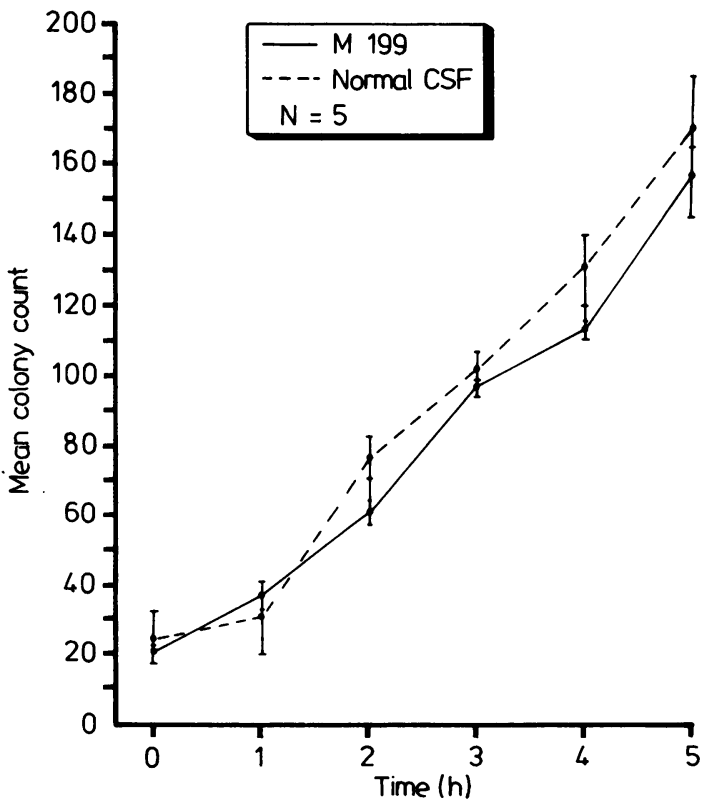

Fig. 3 Growth of pneumococci in medium 199 (M 199) and in normal cerebrospinal fuid. Points represent mean $\pm l$ standard error of the mean; $n=$ number of experiments. 
Table 1 Cerebrospinal fluid effect of dialysis on the inhibitory activity of normal (CSF) on the growth of meningococci.

\begin{tabular}{lll}
\hline Culture medium & $\begin{array}{l}\text { Counts/min } \\
\text { (mean and range) }\end{array}$ & $\begin{array}{l}\% \\
\text { inhibition }\end{array}$ \\
\hline Medium 199 & 23361 & \\
Normal CSF & $(20653-28447)$ & 38 \\
Normal CSF after & 14454 & $\begin{array}{l}(23-53) \\
\text { dialysis }\end{array}$ \\
\hline
\end{tabular}

Results of three experiments are shown.

Table 2 Effect of heat on the inhibitory activity of normal cerebrospinal fuid (CSF) on the growth of meningococci

\begin{tabular}{lll}
\hline Culture medium & $\begin{array}{l}\text { Counts/min } \\
\text { (mean and range) }\end{array}$ & $\begin{array}{l}\% \\
\text { inhibition }\end{array}$ \\
\hline Medium 199 & 21012 & \\
& $(20653-21400)$ & 40 \\
Normal CSF & 12578 & $(32-48)$ \\
& $(11003-14191)$ & 53 \\
Normal CSF & 9914 & $(43-62)$ \\
$56^{\circ} \mathrm{C}$ for 30 min & $(7902-11926)$ & 11 \\
Normal CSF & 18655 & $(10-13)$ \\
$62 \cdot 5^{\circ} \mathrm{C}$ for $30 \mathrm{~min}$ & $(18310-19001)$ & \\
\hline
\end{tabular}

Results of three experiments are shown.

Table 3 Effect of the removal of immunoglobulins on the inhibitory activity of normal cerebrospinal fluid (CSF) on the growth of meningococci

\begin{tabular}{lll}
\hline Culture medium & $\begin{array}{l}\text { Counts/min } \\
\text { (mean and range) }\end{array}$ & $\begin{array}{l}\% \\
\text { inhibition }\end{array}$ \\
\hline Medium 199 & 21442 & \\
& $(20173-22811)$ & \\
Normal CSF & 13209 & 38 \\
& $(11821-14810)$ & $(31-45)$ \\
Normal CSF & 12805 & 40 \\
without immunoglobulins & $(11400-14401)$ & $(33-47)$ \\
\hline
\end{tabular}

Results of three experiments are shown.

CSF was investigated by studying the effect of heating, dialysis, and removal of immunoglobulins. The inhibitory activity of normal CSF on meningococci was removed by dialysis (Table 1 ), reduced by heating to $62 \cdot 5^{\circ} \mathrm{C}$ (Table 2), but it was not impaired by incubation of CSF with antiimmunoglobulin serum (Table 3).

\section{Discussion}

Examination of CSF from patients with pyogenic meningitis immediately after collection showed that samples from patients with pneumococcal meningitis tended to have higher CSF bacterial counts than samples from patients with meningococcal meningitis. The mean CSF bacterial count of patients with pneumococcal meningitis was eight times higher than that observed in patients with meningococcal meningitis, a difference similar to that found in a previous study undertaken in our laboratory, in which a 10 fold difference was found. ${ }^{3}$ Bacteria present within CSF leucocytes were not counted, but in our experience few CSF leucocytes contain bacteria before the start of treatment in patients with either meningococcal or pneumococcal meningitis. CSF white cell counts were considerably lower than CSF bacterial counts and similar in both groups of patients. Even if it is assumed that each CSF leucocyte from a patient with meningococcal meningitis contained one pair of bacteria while none in the CSF of patients with pneumococcal meningitis did so, a five fold difference in total CSF bacterial count between the two groups of patients would still have been observed.

The results of our study, which have shown that normal CSF has an inhibitory effect on the growth of meningococci but not on pneumococci, provide one possible explanation for the higher CSF bacterial count of patients with pneumococcal meningitis compared with patients with meningococcal meningitis. The inhibitory effect was abolished by dialysis of normal CSF, indicating that the inhibitory factor has a low molecular weight. Heating normal CSF to $62.5^{\circ} \mathrm{C}$ for $30 \mathrm{~min}$ resulted in a considerable reduction in the inhibitory effect, indicating that the inhibitor is heat labile at this temperature. Heating normal CSF to $56^{\circ} \mathrm{C}$ for $30 \mathrm{~min}$, however, enhanced inhibition of meningococcal growth. Antibody does not seem to be the inhibitory factor since removal of immunoglobulins from normal CSF did not result in the abolition of the inhibitory effect. The results of these studies also showed that meningococci were inhibited in pneumococcal CSF and vice versa. This could possibly be attributed to increased lysozyme content in the two types of diseased CSF. ${ }^{4}$

Although there have not been any previous reports of normal CSF exerting an inhibitory effect on bacterial growth, there are a number of precedents for biological fluids showing such an effect on bacteria. Inhibition of bacterial growth may result from a series of complex reactions involving substances normally present in body fluids or secretions and bacterial products. For example, ascorbic acid in conjunction with hydrogen peroxide has a bactericidal effect on a number of Gram negative organisms. ${ }^{5}$ Ascorbic acid is present in normal CSF. ${ }^{6}$ It is of low molecular weight (176.12) and therefore dialysable. Hydrogen peroxide is produced during normal metabolic activity of bacteria. It is therefore conceivable that such an inhibitory mechanism on the growth of meningococci might be operating in normal CSF.

Another inhibitory system affecting bacterial growth is that mediated through certain organic 
acids present in normal CSF such as lactic acid' and pyruvic acid. ${ }^{8}$ If lactic acid was the important factor, however, samples from patients with meningitis would be expected to be much more inhibitory than normal CSF. This was not the case.

Regardless of its exact mechanism, the inhibitory effect of CSF on the growth of meningococci, but not pneumococci, may be one of the reasons why patients with pneumococcal meningitis have higher CSF bacterial counts than patients with meningococcal meningitis and why the prognosis of patients with pneumococcal meningitis is so much worse than that of patients with meningococcal meningitis.

BMG and HCW were supported by the United Kingdom Medical Research Council.

\section{References}

' Greenwood BM, Whittle HC, Dominic-Rajkovic O. Countercurrent immunoelectrophoresis in the diagnosis of meningococcal infections. Lancet 1971;ii:519-21.
${ }^{2}$ Whittle HC, Tugwell P, Egler LJ, Greenwood BM. Rapid bacteriological diagnosis of pyogenic meningitis by latex agglutination. Lancet 1974;ii:619-21.

${ }^{3}$ Greenwood BM. A cerebrospinal fluid leucocidin in pyogenic meningitis. J Clin Pathol 1978;31:688-91.

${ }^{4}$ Brathid D, Bøvre K. Bacteriolytic activity of normal and pathological cerebrospinal fluid. Acta Pathol Microbiol Scand (C) 1977;85:21-5.

${ }^{5}$ Miller TE. Killing and lysis of gram-negative bacteria through the synergistic effect of hydrogen peroxide, ascorbic acid and lysozyme. J Bacteriol 1969;98:949-55.

- Spiegel-Adolph M, Mycis HT, Spiegel EA. Chemical analysis of spectrometric findings in cerebrospinal fluid. J Nerv Ment Dis 1951;113:529-37.

${ }^{7}$ Glaser J. The lactic acid content of cerebrospinal fluid. $J$ Biol Chem 1962;69:539-47.

${ }^{8}$ Amatuzia DS, Nesbitt S. Study of pyruvic acid in blood and spinal fluid of patients with liver disease with and without hepatic coma. J Clin Invest 1950;29:1486-90.

Requests for reprints to: Dr M Hassan-King, Medical Research Council Laboratories, Fajara, Near Banjul, The Gambia, West Africa. 